\title{
TEN GELEIDE
}

\section{Hoe vullen we de gevangeniscellen?*}

\author{
Sigrid van Wingerden
}

De criminaliteit in Nederland is de afgelopen jaren gedaald. De statistieken in het rapport Criminaliteit en rechtshandhaving 2014 tonen aan dat de criminaliteit die geregistreerd is bij de politie de laatste jaren steeds minder is geworden. ${ }^{1} \mathrm{Nu}$ zou dit te maken kunnen hebben met het feit dat de politie (vanwege de reorganisatie naar een Nationale Politie?) minder criminaliteit heeft opgespoord: de dalende criminaliteit zou dan meer een registratie-effect zijn dan een feitelijke daling. Maar ook uit zelfrapportages van burgers blijkt dat het slachtofferschap onder burgers is afgenomen. ${ }^{2}$ Er vindt dus steeds minder criminaliteit plaats: Nederland is veiliger geworden. Dat is goed nieuws, toch?

Zeker, maar niet voor de mensen die werkzaam zijn in penitentiaire inrichtingen: als de dalende trend doorzet, hebben we niet genoeg veroordeelden om de cellen te vullen. Prognoses van het Wetenschappelijk Onderzoek- en Documentatiecentrum (WODC) wijzen er bovendien op dat de behoefte aan celcapaciteit de komende jaren nog verder zal dalen. Elf justitiële inrichtingen worden daarom met sluiting bedreigd. ${ }^{3}$ Wat kunnen we daaraan doen?

Staatssecretaris Dijkhoff heeft afgelopen juni een brief naar de Tweede Kamer gestuurd, waarin hij de uitkomsten van onderzoeken naar de capaciteitsbehoefte van het gevangeniswezen samenvat. ${ }^{4}$ Het aantal benodigde cellen is namelijk afhankelijk van vele factoren, zoals de opsporingscapaciteit en de ophelderingspercentages. Smit en Wartna van het WODC hebben voor deze factoren berekend welke invloed zij op de benodigde celcapaciteit hebben. ${ }^{5}$ Verhoging van de opsporingscapaciteit zal volgens hun berekeningen maar een beperkt effect hebben. Als het ophelderingspercentage toe zou nemen van $25 \%$ naar $26 \%$, dan levert dat 93 extra benodigde cellen op in 2021. En bij een verhoging van het ophelderings-

* Mr. dr. Sigrid van Wingerden is als universitair docent Criminologie verbonden aan het Instituut voor Strafrecht \& Criminologie van de Universiteit Leiden. Zij is tevens voorzitter van de redactie van PROCES.

1 S. Kalidien \& N.E. de Heer-de Lange (red.), Criminaliteit en rechtshandhaving 2014. Ontwikkelingen en samenhangen, Den Haag: CBS, WODC, Raad voor de rechtspraak 2015, te downloaden via www.wodc.nl/onderzoeksdatabase/2651-cenr-2014.aspx.

2 Kalidien \& De Heer-de Lange 2015.

3 Kamerstukken II 2015/16, 24587, 655.

4 Kamerstukken II 2015/16, 24587, 655.

5 P.R. Smit \& B.S.J. Wartna, De invloed van verschillende factoren op de behoefte aan celcapaciteit, Factsheet 2016-3, Den Haag: WODC 2016, te downloaden via https://www.rijksoverheid.nl/ documenten/rapporten/2016/06/14/bijlage-2-de-invloed-van-verschillende-factoren-op-debehoefte-aan-celcapaciteit. 
percentage van gewelds- en zedendelicten van 10 procentpunt zouden maar 408 extra cellen nodig zijn. Deze stijging in ophelderingspercentages zijn overigens niet makkelijk te realiseren: er is $20 \%$ extra opsporingscapaciteit bij de politie nodig om het ophelderingspercentage met 1 procentpunt te doen stijgen. Bovendien kan meer politie-inzet ook tot daling van de criminaliteit leiden vanwege het preventieve effect. ${ }^{6}$

Naast de gevolgen van het verhogen van de opsporings- en ophelderingscapaciteiten is ook bekeken of de cellen in de toekomst niet kunnen worden gevuld door de tenuitvoerlegging van openstaande vrijheidsstraffen. Maar ook hiervan moet niet te veel worden verwacht. Het gaat om grofweg 1500 jaar openstaande gevangenisstraf, die over enkele jaren verspreid ten uitvoer zullen worden gelegd. Het effect hiervan is dus maar tijdelijk. Datzelfde geldt voor het wegwerken van de werkvoorraden in de keten. En ook het versoberde gevangenisregime, dat via een hogere recidivekans tot meer benodigde cellen zou kunnen leiden, zal hooguit enkele tientallen extra bedden per jaar vullen. ${ }^{7}$

Het lijkt er dus op dat we in de toekomst niet hoeven te verwachten dat het weer druk wordt in de gevangenissen. Toch heeft staatssecretaris Dijkhoff in de brief beloofd uitvoering te geven aan de motie die de Tweede Kamer heeft aangenomen, waarin stond dat sluiting van gevangenissen aanvullend op het Masterplan nu niet aan de orde is. Dijkhoff voegt daar wel aan toe: 'Het openhouden van gevangenissen beïnvloedt overigens wel de keuzemogelijkheden in de begroting van V\&J.' Hier wordt niet verder op ingegaan, maar het lijkt mij een belangrijk punt. Ook al laten alle prognoses zien dat we de komende jaren met een cellenoverschot blijven zitten, dan nog pompen we liever geld in die leegstaande cellen dan in bijvoorbeeld de re-integratie van ex-gedetineerden. Wat zegt de zoektocht van de staatssecretaris naar mogelijke oplossingen om de cellen te vullen over het ultimum remedium-karakter van de gevangenisstraf? De gevangenisstraf lijkt nu eerder een primum remedium-karakter te hebben. Zouden we vanuit de ultimum remedium-gedachte niet blij moeten zijn als er cellen leegstaan? En kan het probleem van het banenverlies onder penitentiair inrichtingenwerkers niet opgelost worden door het sobere gevangenisregime weer wat minder sober te maken. Dat lijkt mij een win-winsituatie.

Winst op een heel ander terrein is er onlangs ook door slachtoffers van ernstige misdrijven geboekt. Zij hebben sinds 1 juli jl. onbeperkt spreekrecht gekregen. Dat betekent dat zij zich niet alleen in de rechtszaal uit mogen laten over de gevolgen die het delict voor hen heeft gehad, maar ze mogen nu ook wat zeggen over bijvoorbeeld het bewijs en de straf die de verdachte huns inziens zou moeten krijgen. Het eerste artikel in dit nummer van PROCES, van de hand van Giulia de Groot en Sigrid van Wingerden, bevat een systematische literatuurreview naar welke effecten een slachtofferverklaring eigenlijk heeft op de straf die de verdachte krijgt.

Daarna beschrijven Anneke Menger en Lous Krechtig hoe het eraan toeging bij de pilot ZSM-werkplaatsen, waarin officieren van justitie en reclasseringswerkers 
nauw met elkaar samenwerkten in het kader van betekenisvol en contextgericht sanctioneren. Deze pilot heeft ertoe geleid dat informatie beter gedeeld wordt, dat er meer aandacht is voor verdachten die weliswaar lichte delicten plegen, maar waar wel zware problematiek aan ten grondslag ligt, en dat het reclasseringswerk verder vooraan in de strafrechtsketen een plaats heeft gekregen. Het klinkt veelbelovend!

Het PROCESperikel is deze keer geschreven door Daniëlle Kretz, die als programmacoördinator Zelfbeschikking bij het ministerie van Sociale Zaken en Werkgelegenheid probeert te voorkomen dat het zelfbeschikkingsrecht van mensen wordt geschonden, bijvoorbeeld door uithuwelijking. Zij zet uiteen wat er gedaan wordt om mensen bewust te laten worden dat ze het recht hebben om zelf keuzes te maken over hun eigen leven, zoals de campagnes 'Trouwen tegen je wil' en 'Praten over jouw keuzes'.

Daarna volgt een bijdrage van Linda Harmsen over de rechtmatigheid van dynamische verkeerscontroles. Deze controles zijn voor de politie een belangrijk instrument in de strijd tegen criminaliteit, maar zij staan op gespannen voet met het verbod op détournement de pouvoir. Harmsen bespreekt wat een recente uitspraak van de Hoge Raad betekent voor de rechtmatigheid van georganiseerde en spontane dynamische verkeerscontroles.

Vervolgens bepreken Ilse van Leiden, Manon Hardeman en Anton van Wijk de resultaten van hun onderzoek naar de toepassing van het houdverbod. De rechter kan in geval van mishandeling of verwaarlozing van dieren als bijzondere voorwaarde bij een voorwaardelijke straf de dader verbieden om dieren te houden. Uit het onderzoek blijkt dat dit slechts in één op de dertig gevallen van dierenmishandeling of -verwaarlozing gebeurt. De onderzoekers bepreken de invulling van het houdverbod, de doelgroep en de handhaving. Zij concluderen dat de mogelijkheden van het houdverbod nog onvoldoende benut worden en dat de handhaving nog tekortschiet.

Dit nummer van PROCES sluit weer af met de rubriek PS van een redacteur. Coosje Peterse beschrijft daarin deze keer het moeizame verloop van een ISDmaatregel doordat de betrokken instanties steeds naar elkaar verwijzen. Dit leidt tot een hoop frustratie. 